\title{
Питання психології
}

УДК 159.92

DOI: $10.33099 / 2617-6858-21-59-1-93-98$

Dmytrenko M. Y. Doctor of Philosophy, Professor,Cherkasy Institute of Fire Safety named after Chornobyl Heroes of National University of Civil Defence of Ukraine https://orcid.org/0000-0002-8338-4032

Kryshtal M. A. Ph. D. in Psychology, Professor, Cherkasy Institute of Fire Safety named after Chornobyl Heroes of National University of Civil Defence of Ukraine https://orcid.org/0000-0003-0701-4731

Golovchenko S. I. Ph. D. in Economics, Cherkasy Institute of Fire Safety named after Chornobyl Heroes of National University of Civil Defence of Ukraine https://orcid.org/0000-0002-6782-5221

\section{NATURE AND FEATURES OF MORAL CONSCIOUSNESS AS A PSYCHOLOGICAL, SOCIAL AND CULTURAL FORMATION}

Introduction. The article deals with the issues of morality and moral consciousness, which appear to be of great importance in the period of global political, economic and social changes. The authors identify key features in the study of the phenomena, which help to characterize the concept and categories related to it. Moral relationships, moral ideals, moral qualities have been analyzed.

Purpose. The purpose of the research is to explore the nature and features of moral consciousness as a psychological, social and cultural formation and look into its components.

Methods. Qualitative methods have been used for data collection as basic methods. To interpret notions related to moral consciousness thematic and content analysis have been applied. We have chosen secondary methods to synthesize the existing theoretical views on the investigated issue. To get an in-depth understanding of the phenomenon and interpret general characteristics of moral consciousness components descriptive methods have been selected.

Originalitv. Having conducted content and thematic analysis of foreign and domestic research papers, the authors found out that it is expedient to explore the issue at the intersection of three planes. They are psvchological, social and cultural. These planes have a strong impact on the interpretation of the concept, its nature and features. Another significant factor that explains the topicality of the problem is the transformations in values caused by the global changes in all the fields of human activities. Material world proves to have a total dependence on social, cultural and psychological factors. Moreover, moral awareness guides an individual in his/her professional activities. It helps to maintain social order and is the foundation for corporate culture. The research sets the grounds for the deeper study of moral principles, moral motives, moral norms and moral responsibility existing in the modern society.

Conclusion. The authors conclude that moral consciousness is a multi-faceted formation reflected in psychological, social and cultural planes. It is an integral part of an individual's development. It is briefly defined as the individual's awareness of morality. It has its tiers, features, structure and peculiarities. The structure falls into the categories of cognitive, value, emotional and behavioral aspects of an individual.

Further research can be carries out in terms of practical assessment of the impact of various factors on the development of the individual's moral consciousness. values.

Keywords: moral consciousness; morality; psychological, social, cultural formation; personality; moral

Research problem formulation. Current trends of developing professional competence enhance the requirements to the level of social and psychological well-being of the future specialists of all areas of human activities. The topicality of the problem is explained by several reasons. Constant changes in the political, economic and social life in Ukraine lead to transformations in values. It often results in frustration and even the deformation of ethical and worldview ideas. Material world proves to have a total dependence on social, cultural and psychological factors. Moreover, moral awareness guides an individual in his/her professional activities. It helps to maintain social order and is the foundation for corporate culture.

Analysis of the latest research and publications. The phenomenon of social consciousness has been in the focus of attention of foreign and domestic researchers since they started investigating the development of an individual and the society. Philosophers, sociologists, psychologists, lawyers, political scientists, methodologists have addressed both general principles and developmental questions. 


\section{Питання психології}

Moral and ethical consciousness have been investigated by K. Albukhanova-Slavska, S. Anisimov, L. Bozhovych, A. Brushlinsky, B. Lomov, etc. New approaches to the issue with rich history have been revealed in the latest publications. P.S. Churchland considers morality in the plane of neuroscience [2], S. Polonski deals with the influence of artificial intelligence on moral consciousness [7]. $\mathrm{M}$. Tomasello, A. Vaish [9], N. Ellemers [3] focus on morality in human cooperation and social identity.

The purpose of the research. The purpose of the research is to explore the nature and features of moral consciousness as a psychological, social and cultural formation and look into its components.

Research methods. Qualitative methods have been used for data collection as basic methods. To interpret notions related to moral consciousness thematic and content analysis have been applied. We have chosen secondary methods to synthesize the existing theoretical views on the investigated issue. To get an indepth understanding of the phenomenon and interpret general characteristics of moral consciousness components descriptive methods have been selected.

Main body. Moral consciousness is believed to be a complex phenomenon. We tend to agree with the idea expressed by G. H. Frímannsson that it is next to impossible to give an exact definition of concepts like morality and set some boundaries for them. It is better to describe them and give examples [4]. Content analysis enabled us to prove that there is no single opinion on how to define this phenomenon. We have explored it in three planes: psychological, social and cultural. Psychology interprets it as an important part of an individual's psychological structure. In terms of culture, we understand it as the awareness of the needs for spiritual development reflected in their habits, behavior, moral and religious beliefs. In the social plane, it is understood as being aware and responsive to the requirements exposed to an individual belonging to some social group, performing social roles and interacting with the other individuals. As we can see, all three areas are closely connected with each other and cannot be studied separately.

There is some argue among scholars about the difference between morality and moral consciousness. In our opinion, morality is a wider notion meaning a system of moral principles and values while moral consciousness is the process of receiving and processing morality.

Moral consciousness as an element of morality is considered to be a combination of feelings, beliefs, norms, principles, evaluative judgments, which express its spiritual side. It is a form of reflection and spiritual development of reality. It is based on interpersonal relationships, social life and has an objective character. The development of social life determines the changes and development of moral consciousness. Similarly to social consciousness, moral consciousness requires relative freedom and independence of development.

Moral consciousness is a complex phenomenon of the individual's spiritual culture, which has its own levels, forms and structure. It functions on rational-theoretical and emotional-sensory levels, which are inseparable and complement each other. In modern science, there are various views on the nature, functions and features of moral consciousness manifestation. Thus, R.V. Pavelkiv considers moral consciousness as a special construct of the psyche that provides understanding and acceptance of moral laws and organizing their own behavior according to them. Moral consciousness, according to the author, is a cultural and psychological phenomenon, which is an important component of social and individual life. It is one of the components of human consciousness, which reflects the degree of assimilation of social morality, assimilation, interpretation, and sometimes human development of moral principles [8, c. 40]. Another understanding of moral consciousness is offered by O. Bondarevska. In particular, she emphasizes that the moral consciousness of the individual is a process of reflection by individual consciousness of the moral aspect of social events and acts of behavior, as a result of which their moral evaluation is carried out. The researcher also identifies the components of moral consciousness. They are:

- normative, which include moral knowledge, moral concepts, principles, ideas that express society's requirements for human behavior and have become the property of the individual;

- evaluation, which include evaluation and self-evaluation, conscious evaluation criteria, which are used by the individual in practice;

- regulatory, which include feelings, attitudes, beliefs and other components of 


\section{Питання психології}

consciousness that influence the behavior of the individual [11].

Depending on the bearer, moral consciousness is divided into social and individual. Society is considered to be the bearer of social moral consciousness. It is based on the experience of the past generations and historical epochs. Social moral consciousness is also structured on two levels. The basis for its emotional level is made of moral feelings, moral judgments and appropriate evaluative ideas. This level of consciousness and its components are quite contradictory, vague and related to the immediate needs of an individual and are more specific, combined with the interests of social groups, communities, pragmatic and utilitarian in nature. Rationaltheoretical level of social moral consciousness has a clear, consistent, rational and systemic nature. Its nature can be characterized as a moral philosophy or ethics. Moral feelings and beliefs are realized in moral activity and moral relations. Moral consciousness is characterized by universality, the ability to make everything the object of its judgment and evaluation from the standpoint of the abstract principles of true humanity.

Social moral consciousness is a holistic phenomenon where the theoretical level is reflected in the system of concepts. The concepts of moral consciousness play an important role in the spiritual and practical development of the world.

Individual moral consciousness in the unity of sensory, rational and volitional components is formed in the interaction with social moral consciousness in everyday life. Moral consciousness is a mental expression of moral normativeness and moral evaluation in the form of some general ideas and specific concepts, as well as the application of these normative-evaluation ideas and concepts to various situations in the form of specific considerations. General moral ideas and concepts (good and evil, a sense of duty and honor, a sense of dignity and conscience, etc.) form the core of moral consciousness. They allow us to consider the human activities from various aspects of moral perception and different morality. Moral consciousness is also the most effective in terms of spiritual contribution to the inner world of the individual, his/her values. The psychological components of the latter are cognitive and emotional value. Moral reflection represents the first component. Moral self-esteem and selfcontrol, self-regulation, the content of which is to perform the functions of coordination, regulation, management, control at the level of the behavioral component of the structure of moral consciousness belong to the second one.

Moral consciousness consists of several tiers:

- theoretical moral consciousness, which includes theories of morality that justify the need for certain behavior, reveal the essence and content of ethical categories, formulate moral ideals and goals;

- everyday moral consciousness (a system of elementary norms of morality, which has absorbed formed over the centuries and millennia the basic rules of human life);

- psychological moral consciousness that has absorbed the simple norms of morality, existing in the thoughts, feelings, values, rooted in the people;

- at the highest level of moral consciousness is moral ideology, which is theoretically grounded, practical moral consciousness, theoretical conclusions of ethics, recognized as correct and necessary, which people use when they are adopted.

Moral philosophy elaborates the clearest, most comprehensive concepts of moral consciousness (ethics, which reveals the highest professional level of theoretical moral consciousness). The most complex and essential of them, reflecting the key areas of moral life, receive the status of a category such as good and evil, sense of life and happiness, duty and conscience, moral choice and responsibility, love, etc.). The formation and meaningful originality of most concepts and categories of ethics are reflected in the history of ethical thought. The complication of moral life, the development of spiritual culture, the formulation and elaboration of theoretical problems of morality, in particular, have led to the fact that the categorical apparatus of ethics, the concept of moral consciousness became more meaningful.

It is commonly accepted that morality serves as a regulator of human behavior. It evaluates the individual's actions, the actions of social actors. So moral evaluation takes an important place in the structure of moral consciousness, which is an idea of the moral values of actions, their compliance with the accepted ones. Moral evaluation uses the notion of good and evil, just and unjust, honest and dishonest. It is expressed in the approval or condemnation of appropriate behavior, actions of the individual, the actions of social institutions and social actors. 


\section{Питання психології}

One of the main elements of morality as a kind of regulator of human behavior is communication. As an invariable component of the personal structure, communication is a universal means of humanizing the person himself. It requires the individual's ability to navigate in various, often contradictory situations, to find moral solutions to problems. According to O. Klepikov, all this, requires a conscious choice of individual behavior, which encourages the development of creative thinking, awareness of goals, objectives, motives, not only the actions themselves, but also their consequences [6, c.7]. Morality in the context of communication is the same dimension that determines a person's behavior, his/her attitude to the interlocutor, covers the inner need of the individual to perform moral actions and deeds. Moral relationships, as an integral part of interpersonal relationships, play a leading role in shaping a new individual, and as an aspect, they are present in all human relationships. Moral relations are a set of special types of connections and dependencies that are restored as a result of relationships with other people, with the society. In the real process of communication, interpersonal relationships reflect morality directly, which cannot exist outside of these relationships. The very process of communication, according to G. Simmel, forms an ideal world in which the joy of each is directly related to the joy of others, and no one can satisfy their desire by dissatisfying others [5].

Gradually, in the process of moral development within the moral consciousness, ideas about the moral qualities of the individual, his/her virtues are developed, which enable living in accordance with the requirements of morality. Value ideas of moral consciousness of good and evil, righteous and sinful are clarified in the moral qualities of the individual. Their content reflects the requirements to an individual as a subject of moral relations.

In addition, the concept of moral ideal is gradually formed as a hypothetical image of morally perfect society and man, as the ultimate goal to which moral development is directed. The moral ideal of the individuals appears in the moral consciousness as a critical rejection of imperfect reality and its spiritual transformation for their own development and improvement. Ideas about the social moral ideal have always reflected the imperfection of real life and hope for a better future, a perfect life (literary and artistic pursuits of the future, sociophilosophical utopias).

Researchers distinguish among various components of moral consciousness. In our research we outline four main ones (see Fig. 1.1):

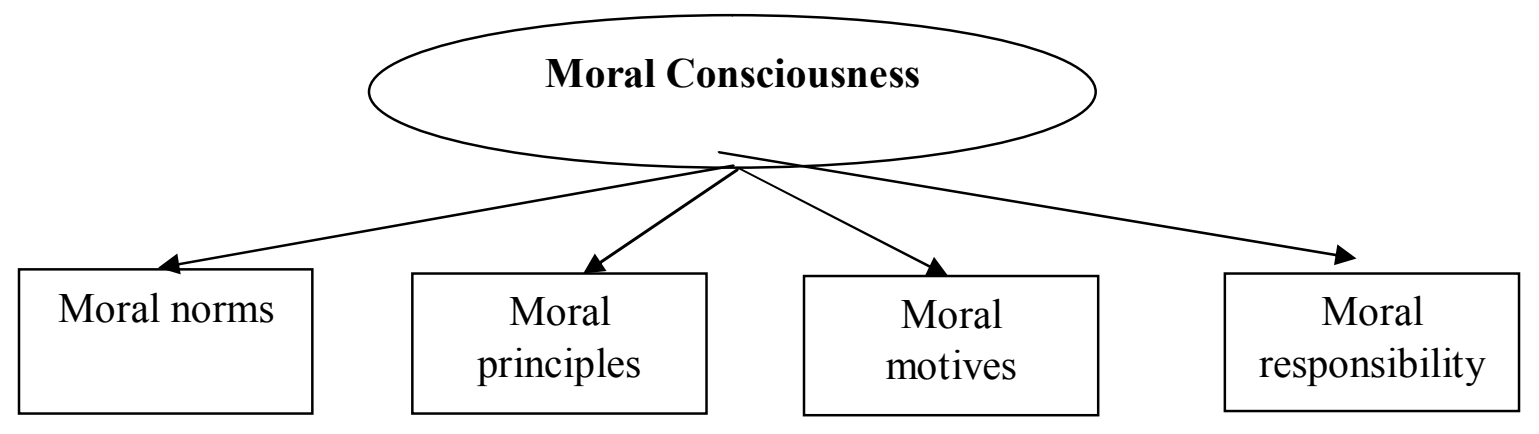

Fig.1.1 The main components of moral consciousness

Let us consider each component. Moral norms are elementary forms of morality of the individual; a certain pattern of behavior that reflects the established needs of human coexistence and relationships and is mandatory. These norms can be general (fundamental) and situational (external culture of behavior and rules of etiquette). The main features of moral norms include: imperative (mandatory); ability to universalize (a separate rule can be summed up as universal); hierarchical nature $[1,11]$.

Moral principles (the principle of justice, diligence, humanism, patriotism, etc.) characterize the integral line of human behavior and are components of moral character. Principles give a person moral rationality and predictability of his behavior. They are not strictly obligatory.

A person can be aware of moral norms and have moral principles, but, at the same time, can do nothing for their practical implementation. This requires motives, the individual's interest in a particular action, and the answer to the question "why" actually, he did it. The moral value of an action does not always correspond to the moral value of the motive underlying it. 


\section{Питання психології}

Moral responsibility as a component of moral consciousness is understood as determining the conformity of behavior, actions, results of human action to the content of moral norms, his duty, taking into account the objective circumstances and the possibility of their implementation. Responsibility means that a person assumes responsibilities and is ready to perform them freely to the best of ability, as well as to be accountable to the society, community, other people and to himself/herself for moral views, values, guidelines, for the correct understanding of obligations, for the content of the actions.
Conclusions. Moral consciousness is a multi-faceted formation reflected in psychological, social and cultural planes. It is an integral part of an individual's development. It is briefly defined as the individual's awareness of morality. It has its tiers, features, structure and peculiarities. The structure falls into the categories of cognitive, value, emotional and behavioral aspects of an individual. Further research can be carried out in terms of practical assessment of the impact of various factors on the development of the individual's moral consciousness.

\section{Список використаних джерел}

1. Ананьєв Б. Г. Структура особистості і працездатності / Б.Г. Ананьєв. Л., 1966. 110-118 с. 5.

2. Churchland, P. S. (2011). Braintrust: What neuroscience tells us about morality. Oxford, UK: Princeton University Press

3. Ellemers, N. (2018). Morality and social identity. In Van Zomeren, M., Dovidio, J. (Eds.), The Oxford handbook of the human essence (pp. 147-158). Oxford, UK: Oxford Library of Psychology, Oxford University Press.

4. Guðmundur Heiðar Frímannsson Moral and historical consciousness Режим доступу:https://www.researchgate.net/publication/319955855_Moral_and_historical_consciousness

5. Зиммель Г. Избранное [Електронний ресурс] : $\overline{\text { в }} 2$ т. М. жизни. Режим доступу: http://www.Krootov.Info/ Iibr-min/z/zimme12htmI

6. Клепіков О. І. Основи творчості особи. К. : Вища шк., 1996. 295 с.

7. Polonski S. Can we teach morality to machines? Three perspectives on ethics for artificial intelligence [Електронний ресурс] Режим доступу: https://medium.com/@drpolonski/can-we-teach-morality-tomachines-three-perspectives-on-ethics-for-artificial-intelligence-64fe479e25d3

8. Павелків Р.В. Розвиток моральної свідомості та самосвідомості: автореф. Дис. На здобуття наук. Ступеня д-ра. Психолог. Наук: спец. 19.00.07 “Педагогічна та вікова психологія" . К., 2005. С. 40.

9. Tomasello, M., Vaish, A. (2013). Origins of human cooperation and morality. Annual Review of Psychology, 64, 231-255.

10.Фомич Н.В. Воспитание духовно-нравственных ценностей будущих специалистов службы гражданской защиты ГСЧС Украины в процессе их профессиональной подготовки / Н.В. Фомич, С.А.Мукомел, Л.И. Мохнар // Influence of knowledge and public practice on the development of creative potential and personal success in life. - London, 2016. - p. 31-32.

11.Шугорский В.А. Психология моральности: Учебное пособие. М.: Издательский центр «Академия», 2003. - 240 с.

\section{References}

1. Ananiev B.G. (1966) Struktura osobystosti I pratsezdatnosti [Structure of an individual and working capacity]. L. p. 110-118. (in Ukrainian).

2. Churchland, P. S. (2011). Braintrust: What neuroscience tells us about morality. Oxford, UK: Princeton University Press (in English).

3. Ellemers, N. (2018). Morality and social identity. In Van Zomeren, M., Dovidio, J. (Eds.), The Oxford handbook of the human essence (pp. 147-158). Oxford, UK: Oxford Library of Psychology, Oxford University Press. (in English).

4. Guðmundur Heiðar Frímannsson Moral and historical consciousness URL: https://www.researchgate.net/publication/319955855_Moral_and_historical_consciousness (in English).

5. Zimmel G. (1996) Sozertsaniye zhyzni [Observing life] URL: http://www.Krootov.Info/ Iibr$\mathrm{min} / \mathrm{z} /$ zimme12htmI. (in Russian).

6. Klepikov O.I. (1996) Osnovy tvorchosti osoby [Fundamentals of the individual's creativity] K. : Vyshcha shkola. 295 p. (in Ukrainian).

7. Polonski S. Can we teach morality to machines? Three perspectives on ethics for artificial intelligence URL: https://medium.com/@drpolonski/can-we-teach-morality-to-machines-three-perspectives-on-ethics-forartificial-intelligence-64fe479e25d3 (in English).

8. Pavelkiv R.V. (2005) Rozvytok moralnoi svidomosti ta samosvidomosti [Development of moral consciousness and self-conscioussness]: avtoref. dys. Na zdobuttia nauk. stupenia d-ra psykholoh. nauk: spets. 19.00.07 "Pedahohichna ta vikova psykhologia" K. (in Ukrainian). 


\section{Питання психології}

9. Tomasello, M., Vaish, A. (2013). Origins of human cooperation and morality. Annual Review of Psychology, 64, 231-255. (in English).

10.Fomich N.V. (2016) Vospitanie duhovno-nravstvennyh cennostej budushhih specialistov sluzhby grazhdanskoj zashhity GSChS Ukrainy $\mathrm{v}$ processe ih professional'noj podgotovki / N.V. Fomich, S.A.Mukomel, L.I. Mohnar // Influence of knowledge and public practice on the development of creative potential and personal success in life. London. p. 31-32. (in Russian). Russian).

11.Shugorsji V.A. (2003) Psikhologiya moralnosti [Psychology of morality]. M.: Akademiya. (in

\section{Резюме}

Дмитренко М. Й. доктор философских накк, профессор, Черкасский институт пожарной безопасности имени Героев Чернобыля Наџионального университета гражданской обороны Крышталь Н. А. кандидат психологических наук, профессор, Черкасский институт пожарной безопасности имени Героев Чернобыля Головченко С. И. кандидат экономических наук, Черкасский інститут пожарной безопасности имени Героев Чернобыля Наџионального университета гражданской оборонь

\section{СУЩНОСТЬ И ОСОБЕННОСТИ МОРАЛЬНОГО СОЗНАНИЯ КАК ПСИХОЛОГИЧЕСКОЙ, СОЦИАЛЬНОЙ И КУЛЬТУРНОЙ ФОРМАЦИИ}

Статья посвящена исследованию сущности и особенностей морального сознания как психологической, сочиальной и культурной формачии. Авторы характеризуют изучаемое явление в соответствии с различными факторами: носителем, психологическими компонентами, уровнями сформированности. Освещены понятия нравственных отномений, моральных качеств и нравственного идеала. Представлено краткое описание основных общепринятых составляюших морального сознания.

Ключевые слова: моральное сознание; нравственность; психологическая, сочиальная, культурная формация; личность; нравственные ценности

\section{Резюме}

Дмитренко М. Й. доктор філософських наук, профессор, професор кафедри психології діяльності в особливих умовах, Черкаський інститут пожежної безпеки імені Героїв Чорнобиля Національного університету цивільного захисту України Кришталь М. А. кандидат психологічних наук, професор, Черкаський інститут пожежної безпеки імені Героїв Чорнобиля Національного університету цивільного захисту Украӥни Головченко С. I. кандидат економічних наук, старший викладач кафедри психології діяльності в особливих умовах, Черкаський інститут пожежної безпеки імені Героїв Чорнобиля Національного університету иивільного захисту Украӥни

СУТЬ І ОСОБЛИВОСТІ МОРАЛЬНОЇ СВІДОМОСТІ ЯК ПСИХОЛОГІЧНОЇ, СОЦІАЛЬНОЇ І КУЛЬТУРНОЇ ФОРМАЦІЇ

Стаття присвячена дослідженню сутності $i$ характеристик моральної свідомості як психологічної, сочіальної та культурної формачії. Трансформачія цінностей, спричинена глобальними змінами у всіх сферах людської діяльності слугуе вагомим чинником, що пояснюе актуальність проблеми. У досліджені використані якісні методи для збору даних. Для інтерпретації понять, пов'язаних із моральною свідомістю, застосовано тематичний $i$ контент аналіз. Для глибшого розуміння явища та інтерпретащії загальних характеристик компонентів моральної свідомості обрані описові методи. Автори характеризують досліджуване явище за різними чинниками: носієм, психологічними компонентами, рівнями сформованості. Висвітлено поняття моральних відносин, моральних якостей $i$ морального ідеалу. Здійснено стислий опис основних загальноприйнятих складових моральної свідомості. Автори доходять висновку про те, що моральна свідомість $\epsilon$ багатогранною формацією, яке відтворюється у поєднанні психологічної, соціальної та культурної плошин. Це невід'ємна частина розвитку особистості. Доведено, що досліджуване явище має свої рівні, характерні особливості та структуру. Остання поділясться за когнітивним, иіннісним, емоційним та поведінковим аспектами особистості.

Ключові слова: моральна свідомість; моральність; психологічна, сочіальна, культурна формація; особистість; моральні иџінності

Автори заявляють про відсутність конфлікту інтересів.

Recelved/Поступила: 29.01. 21. 